\title{
Kinetics of DPPH' scavenging by bacterioruberin from Haloferax alexandrinus GUSF-1 (KF796625)
}

\author{
Jyothi Judith Alvares and Irene Jeronimo Furtado* (i)
}

\begin{abstract}
This is the first account of the kinetics of free radical scavenging by bacterioruberin obtained from cells of Haloferax alexandrinus GUSF-1(KF796625), grown at optimum conditions of $25 \% \mathrm{NaCl}, \mathrm{pH} 7,42^{\circ} \mathrm{C}, 150 \mathrm{rpm}$ in $\mathrm{NaCl}$ Tryptone yeast extract medium and light. Bacterioruberin separated from methanolic extract displayed characteristics absorption peaks at 368, 386, 463, 492 and $525 \mathrm{~nm}$ and gave an $\mathrm{m} / \mathrm{z}$ value of $740.4\left(\mathrm{C}_{50} \mathrm{H}_{76} \mathrm{O}_{4}\right)$ in Liquid ChromatographyMass Spectroscopy validating its purity. Bacterioruberin (13 $\mu \mathrm{M})$ decolorized and decayed $0.2 \mathrm{mM}$ 1,1-diphenyl-2-picrylhydrazyl radicals (DPPH') monitored at $517 \mathrm{~nm}$ and reached a steady state within $30 \mathrm{~min}$. An EC 50 of $6.50 \mu \mathrm{M} \pm 0.27$ $(4.81 \mathrm{\mu g} / \mathrm{mL} \pm 0.2)$ was deduced for the $0.2 \mathrm{mM} \mathrm{DPPH}^{*}$-bacterioruberin reaction using the GraphPad Prism 9 statistical software and employing the right-angled triangle technique. The study also revealed a comprehensive information of the total kinetic activity of bacterioruberin with DPPH': the antioxidant activity index was $16.38 \pm 0.67$; time needed to reach the steady state with the added $\mathrm{EC}_{50}-30 \mathrm{~min}$; the antiradical power $30.77 \pm 1.27$ and the antiradical efficiency of $54.7 \times 10^{-3} \pm 2.24$, thus reflecting the strong antioxidant nature of bacterioruberin. Scavenging of $\mathrm{DPPH}^{*}$ by bacterioruberin was a pseudo-first-order reaction with a rate constant $k_{2}$ of $2.76 \times 10^{-5} \pm 0.001 \mu^{-1} \mathrm{~s}^{-1}$ calculated at $t=0$ or initial time and $t=30 \mathrm{~min}$. The knowledge of the kinetics of bacterioruberin to scavenge DPPH adds to its effective application as an antioxidant in medicinal use, pharmaceutical products and others. Additionally, the use of simple conventional method of DPPH free radical scavenging, monitored using an easily available laboratory spectrophotometer, will certainly help in the effective use of any antioxidant compound.
\end{abstract}

Keywords: Bacterioruberin, DPPH; Free radical scavenging, Kinetics, Haloferax alexandrinus GUSF-1

\section{Introduction}

Oxidative stress in a biological system is the inability of the body to eliminate the free radical reactive species through the use of endogenous antioxidants (Yusuff et al. 2019). Natural antioxidants are gaining importance as nutraceuticals, dietary supplements (Guerin et al. 2003) and as therapeutic medicines (Firuzi et al. 2011). They are preferred over synthetic antioxidants because of their

\footnotetext{
*Correspondence: ijfurtado@unigoa.ac.in
}

Department of Microbiology, Goa University, Taleigao Plateau, Goa 403206, India

To Jesus Christ-the Way, the Truth and the Life inability to accumulate in the human body and cause harm (Deng et al. 2011).

Antioxidants relieve oxidative stress via: hydrogen atom transfer (HAT), proton coupled electron transfer (PCET), single electron transfer followed by proton transfer (SET-PT), sequential proton loss electron transfer (SPLET), radical adduct formation (RAF) and sequential proton loss through hydrogen atom transfer (SPLHAT) (Marković 2016).

Free radical scavenging of 1,1-diphenyl-2-picrylhydrazyl $\left(\mathrm{DPPH}^{\circ}\right)$ at fixed endpoint has been widely used to evaluate the antioxidant properties of natural compounds capable of scavenging free radicals (Brand-Williams et al. 
1995) and is preferred since it simulates reactive oxygen and nitrogen-free radical species, which affects the biological systems (Arnao 2000). The use of $\mathrm{DPPH}^{*}$ provides an easy and rapid method to evaluate the potential of an antioxidant molecule scavenging free radicals which can be measured as a change in optical density/absorbance and referred to as the strength of the antioxidant. (BrandWilliams et al. 1995).

Knowledge of kinetic parameters such as antiradical efficiency and time required to reach steady-state provides additional information about antioxidant behavior. Hence, they are more informative than mere total antioxidant capacity determinations at fixed endpoint even if carried out by different methods (Sánchez-Moreno et al. 1998).

Bacterioruberin of $\mathrm{C}_{50}$ carotenoid is reported in members from different genera of haloarchaea such as Haloterrigena, Haloarcula, Halobacterium, Halococcus, Halogeometricum, Haladaptatus, Haloplanus, Halopelagius and Halogranum (Squillaci et al. 2017; Yatsunami et al. 2014; Abbes et al. 2013; Mandelli et al. 2012; Hou and Cui 2018); in Haloferax volcanii (Ronnekleiv and Liaaen-Jensen 1995; Hou and Cui 2018), in genetically modified Haloferax volcanii strain (HVLON3) by Zalazar et al. (2019), Haloferax alexandrinus strain $\mathrm{TM}^{\mathrm{T}}$ (Asker et al. 2002) and in Haloferax alexandrinus GUSF-1 (KF796625) (Alvares and Furtado 2021), respectively.

Bacterioruberin, of Halobacterium salinarium, is reported to protect cells in vitro against oxidative damage of UV light and hydrogen peroxide (Shahmohammadi et al. 1998); of Haloferax alexandrinus GUSF-1 (KF796625) to scavenge free radicals (Alvares and Furtado 2018) and of genetically modified Haloferax volcanii strain (HVLON3) in scavenging free radicals and enhancing ram sperm velocity (Zalazar et al. 2019).

Recently, through separation and chemical profiling of the hexanolic cell extracts of Haloferax alexandrinus GUSF-1 (KF796625), the antioxidant property of bacterioruberin and other $\mathrm{C}_{30}, \mathrm{C}_{40}$, and $\mathrm{C}_{50}$ isoprenoids has been confirmed (Alvares and Furtado 2021). Although the authors Zalazar et al. 2019 investigated the antioxidant activity of bacterioruberin obtained from genetically modified Haloferax volcanii strain (HVLON3) and arrived at $\mathrm{EC}_{50}$ value using the decolorization of $\mathrm{DPPH}^{\circ}$ monitored through electron paramagnetic resonance analysis, they did not investigate other kinetic parameters or delve into the kinetics of the $\mathrm{DPPH}^{*}$-bacterioruberin interaction.

Therefore, the present study used bacterioruberin from cells of Haloferax alexandrinus GUSF-1 (KF796625), studied the kinetic parameters and behavior of this bacterioruberin to scavenge the 1,1-diphenyl-2-picrylhydrazyl $\left(\mathrm{DPPH}^{*}\right)$ free radicals using the conventional spectrophotometric method which is simple, reproducible, reliable, can be carried out routinely and does not require sophisticated instrumentation.

\section{Experimental \\ Chemicals and reagents}

Analytical grade chemicals and reagents from Himedia laboratories-India, 1,1-diphenyl-2-picrylhydrazyl $\left(\mathrm{DPPH}^{*}\right)$ from Sigma, USA and silica gel GF254 plates from Merck, Darmstadt, Germany, were used for thinlayer chromatography (TLC). A $0.2 \mathrm{mM}$ solution of $\left(\mathrm{DPPH}^{*}\right)$ was prepared in methanol (97\% purity) and used in the study, further dilutions were done with methanol, as and when required.

\section{Standard curve of DPPH' solution}

The linearity range of the $\mathrm{DPPH}^{*}$ solution was determined. Varying concentrations of $\mathrm{DPPH}^{*}(0-0.2 \mathrm{mM})$ were prepared from $0.2 \mathrm{mM}$ stock solution in methanol and incubated at room temperature $\left(28{ }^{\circ} \mathrm{C}\right)$ in the dark for $30 \mathrm{~min}$. A linear regression was obtained from the curve by plotting the concentrations $\mathrm{v} / \mathrm{s}$ absorbance obtained at $517 \mathrm{~nm}$ (Additional file 1: Fig. S1).

\section{Culturing of Haloferax alexandrinus GUSF-1 (KF796625) for bacterioruberin}

Haloferax alexandrinus GUSF-1 with accession number KF796625, an isolate from a salt pan (Sequeira 1992), was cultured in Tryptone Yeast Extract containing 25\% (w/v) $\mathrm{NaCl}$ (NTYE) (Raghavan and Furtado 2004) and as indicated in results, at different concentrations of $\mathrm{NaCl}$, temperatures, $\mathrm{pH}$ and in the presence of light. Culture broth was withdrawn daily and cells separated out using the centrifuge (Biofuge-Heraeus Stratos; $8000 \mathrm{rpm}, 4{ }^{\circ} \mathrm{C}$, $10 \mathrm{~min}$ ) were washed with $15 \%(\mathrm{w} / \mathrm{v}) \mathrm{NaCl}$. Growth was monitored as dry weight of washed cells. The cells were then extracted in methanol and clear methanolic extracts were obtained on centrifugation. The culture was also grown under conditions yielding optimum growth, and $100 \mathrm{mg}$ of wet washed cells was used to prepare the methanolic extract which was stored at $-20{ }^{\circ} \mathrm{C}$ till further use. All experiments were carried out in triplicates.

\section{Estimation of antioxidant potential of methanolic extracts} The methanolic extract was checked for $\mathrm{DPPH}^{*}$ free radical scavenging, according to Alvares and Furtado (2021). Here, methanolic extract was mixed with $1 \mathrm{ml}$ of $0.2 \mathrm{mM}$ methanolic $\mathrm{DPPH}^{*}(1: 2 \mathrm{v} / \mathrm{v})$ and incubated in the dark $\left(28{ }^{\circ} \mathrm{C}\right)$ for $30 \mathrm{~min}$; thereafter, the absorbance was read at $517 \mathrm{~nm}$. The antioxidant capacity, expressed as the \% $\mathrm{DPPH}^{*}$ radical scavenging activity (\%DPPH $\left.{ }^{*} \mathrm{RSA}\right)$, was calculated using the following equation: 


$$
\% \mathrm{DPPH} \cdot \mathrm{RSA}=\frac{A_{\mathrm{B}}-A_{\mathrm{S}}}{A_{\mathrm{B}}} \times 100
$$

where $A_{\mathrm{B}}$ is the absorbance of $1 \mathrm{~mL}$ of $0.2 \mathrm{mM}$ $\mathrm{DPPH}^{*}+0.5 \mathrm{~mL}$ of methanol and $A_{\mathrm{S}}$ is the absorbance of $1 \mathrm{~mL}$ of $0.2 \mathrm{mM} \mathrm{DPPH}^{*}+0.5 \mathrm{~mL}$ of methanolic extract after incubation for $30 \mathrm{~min}$.

\section{Preparation of bacterioruberin}

The wet pellet obtained by growing culture under physicochemical parameters yielding maximum antioxidant was treated with methanol, and the cell debris were then separated by centrifuging to obtain a clear cell-free methanolic extract of cells. Components from this were then fractionated with distilled hexane and distilled water according to the method of Asker et al. (2002). The pigment was recovered in the hexane layer, washed several times with distilled water and dried over anhydrous sodium sulfate and other impurities were removed using acetone precipitation. The resulting pigmented residue was re-dissolved in hexane. The orange-colored hexanolic extract, containing bacterioruberin, was purified by preparative TLC using a developing system of methanol-chloroform $(7: 93, \mathrm{v} / \mathrm{v})$ in minimum light (Asker et al. 2002). Bacterioruberin was checked for purity by scanning between 300 and $800 \mathrm{~nm}$ using the UV-Vis dualbeam spectrophotometer (UV-1601, Shimadzu, Kyoto, Japan) in quartz cuvettes of $1 \mathrm{~mL}$ volume and $1 \mathrm{~cm}$ path length and methanol as the reference solution. The identity and purity were further re-confirmed and validated using Applied Biosystems API 2000 Liquid Chromatography-Mass Spectroscopy (LC-MS) system with Ion spray Voltage (IS) - 45,000 V; Ion source gas (GS1) - 20.0 psi, $1 \mathrm{ppm}$ lowest sensitivity and analyst software Q1/MS (A1).

\section{Free radical scavenging activity of bacterioruberin by steady-state measurement}

Bacterioruberin in methanol corresponding to $13 \mu \mathrm{M}$ and $1 \mathrm{~mL}$ of $0.2 \mathrm{mM} \mathrm{DPPH}^{*}$ reagent was mixed in the spectrophotometric quartz cuvette and incubated in the dark at $28^{\circ} \mathrm{C}$. The decrease in absorbance of $\mathrm{DPPH}^{*}$ radical was spectrophotometrically monitored at $517 \mathrm{~nm}$, at initial $1 \mathrm{~min}$ and then every $5 \mathrm{~min}$ (1-35 min) until the reaction reached a plateau/steady state. The reaction mixture was also scanned at appropriate intervals using the UV-Probe 2.42 software. The percentage of $\mathrm{DPPH}^{\circ}$ remaining at different intervals was determined according to Mishra et al. 2012 by using Eq. (2)

$$
\% \text { DPPH }{ }^{\cdot} \text { Remaining }=\frac{A_{\mathrm{f}}}{A_{0}} \times 100
$$

where $A_{0}$ is the absorbance of mixture at $517 \mathrm{~nm}$ containing $1 \mathrm{~mL}$ of $0.2 \mathrm{mM} \mathrm{DPPH}^{*}+0.5 \mathrm{~mL}$ of methanol and $A_{\mathrm{f}}$ is the absorbance of the reaction mixture at $517 \mathrm{~nm}$ con-

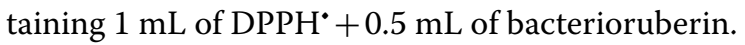

\section{Potency and kinetics of DPPH ${ }^{\circ}$-bacterioruberin interaction}

\section{(i) The effective concentration ( $\mathrm{EC}_{50}$ )}

GraphPad Prism 9 (San Diego, CA) statistical program with the built-in equation for nonlinear regression, i.e. Asymmetric (five-parameter, 5P) was the statistical model used to derive the plot of scavenging of $0.2 \mathrm{mM}$ $\mathrm{DPPH}^{*}$ by bacterioruberin by plotting log concentration of bacterioruberin on the $X$-axis and \% $\mathrm{DPPH}^{\circ} \mathrm{RSA}$ on the $Y$-axis (Chen et al. 2013). The $\mathrm{EC}_{50}$ was then calculated from this log concentration-response curve by using a mathematical method based upon the principle of a right-angled triangle (Alexander et al. 1999). The theoretical value was calculated by using the concentration-effect curve shown in Fig. 4a, wherein the maximum response chosen is a true representation of the $E_{\max }$ and by selecting the two concentrations corresponding to two recorded points on either side of the $50 \%$ maximal response. From the raw data/curve, the values of $A, B, C$, and $D$ are known, and the $50 \%$ maximal response is calculated from minimum (baseline) and maximum responses selected from the raw data.

The $E_{50}$ was derived according to Alexander et al. 1999, using Eq. (3) and compared with $\mathrm{EC}_{50}$ of beta-carotene;

$$
\mathrm{EC}_{50}=D-\frac{(A-50 \% \text { maximal response }) \cdot x}{y}
$$

Further, the time needed to reach the steady state $\left(\mathrm{TEC}_{50}\right)$ at which no further scavenging of $\mathrm{DPPH}^{*}$ takes place at the added $\mathrm{EC}_{50}$ concentration of bacterioruberin was also calculated graphically from the plot of $\% \mathrm{DPPH}^{\circ}$ remaining $\mathrm{v} / \mathrm{s}$ time.

(ii) Antioxidant activity index (AAI) (Scherer and Godoy 2009)

Furthermore, the antioxidant activity index (AAI) was calculated as:

$$
\mathrm{AAI}=\frac{\text { Final concentration of DPPH }(\mu \mathrm{g} / \mathrm{mL})}{\mathrm{EC}_{50}(\mu \mathrm{g} / \mathrm{mL})}
$$

(iii) Antiradical efficiency (ARE) (Sánchez-Moreno et al. 1998) 
Moreover, the antiradical efficiency (ARE) of bacterioruberin was deduced from $\mathrm{EC}_{50}$ value converted to $\mu \mathrm{g} / \mathrm{mL}$ and expressed as $\mathrm{g} \mathrm{BR} / \mathrm{kg} \mathrm{DPPH}{ }^{*}$ and $\mathrm{TEC}_{50}$ at $30 \mathrm{~min}$, as under:

$$
\mathrm{ARE}=\frac{1}{\mathrm{EC}_{50}} \times \frac{1}{\mathrm{TEC}_{50}}
$$

(iv) Antiradical power (ARP) (Mishra et al. 2012)

Additionally, antiradical power (ARP), the antioxidant action was calculated as reciprocal of ratio of $\mathrm{EC}_{50}$ $(\mu$ moles/ $\mu$ mole of DPPH* $)$

$$
\mathrm{ARP}=\frac{1}{\mathrm{EC}_{50}}
$$

(v) Reaction stoichiometry (Brand-Williams et al. 1995)

This was expressed as the amount of $\mathrm{EC}_{50}$ ratio ( $\mu$ moles/ $\mu$ mole of $\mathrm{DPPH}^{*}$ ) of bacterioruberin required to reduce $100 \% \mathrm{DPPH}^{*}$ radicals and was deduced and calculated from $\mathrm{EC}_{50}$ value $\times 2$. From this, the number of $\mathrm{DPPH}^{*}$ molecules reduced by one mole of bacterioruberin was further calculated thereof. (vi) Rate constant (Mishra et al. 2012).

The formation of DPPH-H on addition of different $\mu \mathrm{M}$ concentrations of bacterioruberin to fixed $0.2 \mathrm{mM}$ $\mathrm{DPPH}^{\circ}$ was checked, and the rate constant was calculated from the slope of this plot. All reactions were carried out as five independent experiments and expressed as a mean \pm standard deviation $(n=5)$ derived using Microsoft Excel 2019.

\section{Results and discussion}

Large scale preparation and separation of bacterioruberin Earlier, Alvares and Furtado (2018) demonstrated the decolorization of the deep purple color of $\mathrm{DPPH}^{*}$ by colonies of Haloferax alexandrinus GUSF-1 and also of their methanolic extracts as a consequence of free radicals scavenging activity. In a recent report, Alvares and Furtado (2021) attributed this antioxidant activity to the several compounds present in the cells of Haloferax alexandrinus GUSF-1 among which, the $\mathrm{C}_{50}$ isoprenoid bacterioruberin was most dominant.

As seen in Fig. 1a-d, maximum antioxidant produced by Haloferax alexandrinus GUSF-1 grown, separately at $150 \mathrm{rpm}$ for over a period of 6 days in TYE medium with

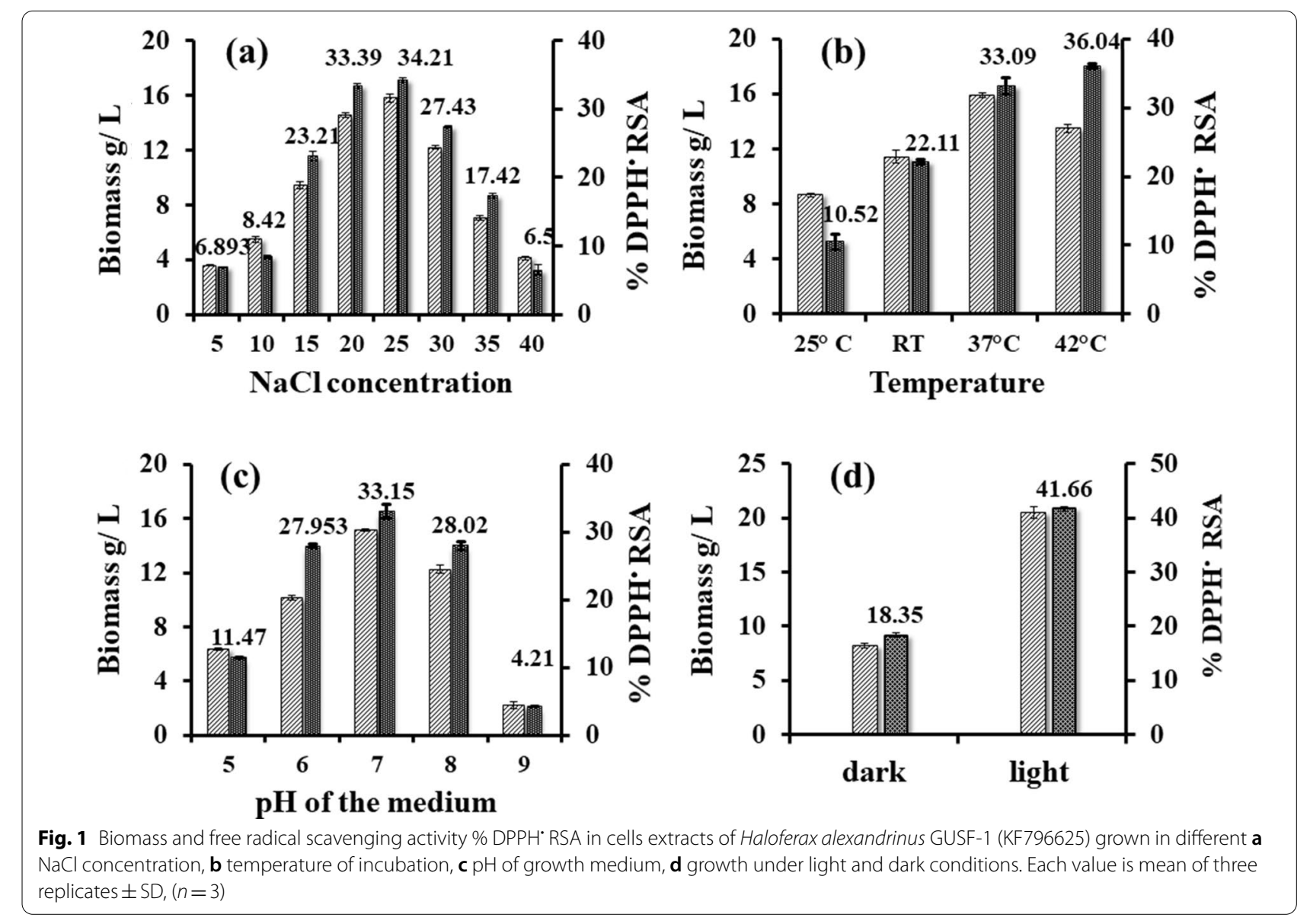




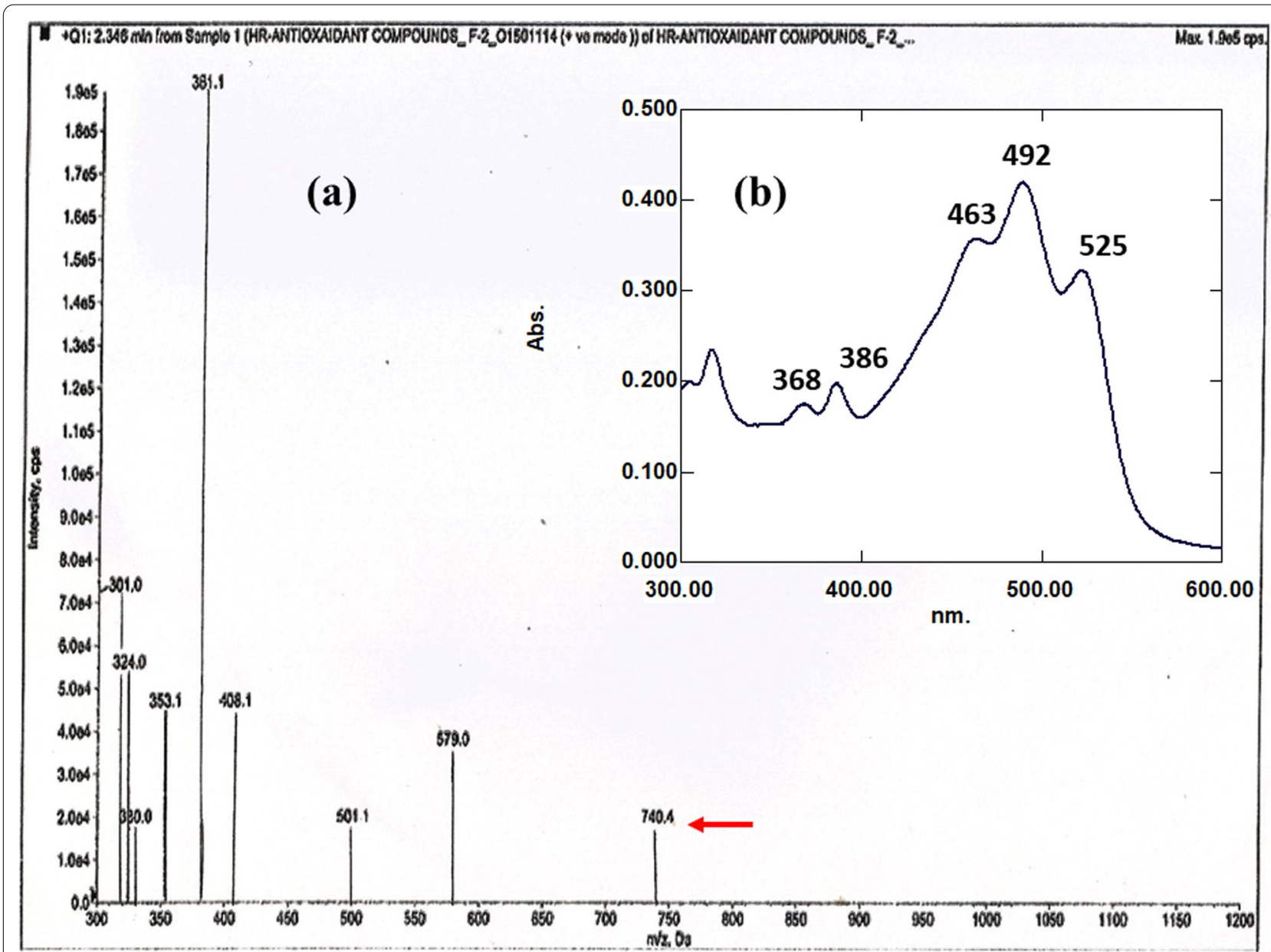

Fig. 2 a Mass spectrum of purified bacterioruberin obtained by Applied Biosystems API 2000 LC-MS system, b visible absorption spectrum of purified bacterioruberin

different concentrations of $\mathrm{NaCl}$, temperature, $\mathrm{pH}$, light and dark gave a maximum of $34.21 \%$ by cells grown in $25 \% \mathrm{NaCl}, 36.04 \%$ at $42^{\circ} \mathrm{C}, 33.15 \%$ in $\mathrm{pH} 7$ and $41.66 \%$ by cells grown in the presence of light and amount of $25 \mu \mathrm{g}$ of bacterioruberin was easily separated at $R_{f} 0.24$ and purified by preparative thin-layer chromatography (PTLC). The recovered bacterioruberin in methanol exhibited characteristic spectral peaks at 368,386 , 463, 492 and $525 \mathrm{~nm}$; and the $m / z 740.4\left(\mathrm{C}_{50} \mathrm{H}_{76} \mathrm{O}_{4}\right)$ of the molecular ion $\left(\mathrm{M}^{+}\right)$detected in LC-MS (Fig. 2a, b) validated its purity. These features were consistent with those reported by Asker et al. (2002) and Alvares and Furtado (2021).

\section{Free radical scavenging activity of bacterioruberin}

The two characteristics absorption peaks of $0.2 \mathrm{mM}$ $\mathrm{DPPH}^{\circ}$ in methanol were observed at $517 \mathrm{~nm}$ and $325 \mathrm{~nm}$, while purified bacterioruberin displayed peaks at $368,386,463,492$ and $525 \mathrm{~nm}$. Spectrophotometric monitoring was employed to decipher the interaction of bacterioruberin with $\mathrm{DPPH}^{*}$ at $517 \mathrm{~nm}$. The addition of bacterioruberin in methanol with one of the absorption peaks at $525 \mathrm{~nm}$ when in contact with the chromogen $\mathrm{DPPH}^{*}$ in a 1:2 ratio instantly reduced the absorption peak of $\mathrm{DPPH}^{\cdot}$ at $517 \mathrm{~nm}$ as displayed in Fig. $3 \mathrm{a}(\mathrm{i}-\mathrm{v})$. Further the peaks at 463, 492 and $525 \mathrm{~nm}$ corresponding to bacterioruberin were completely abolished thus indicating that the interaction of bacterioruberin had no interference in the measurement of $\mathrm{DPPH}^{*}$ at $517 \mathrm{~nm}$. The incremental decrease of the $\mathrm{DPPH}^{*}$ peak at $517 \mathrm{~nm}$ on the addition of bacterioruberin reflected receipt of $\mathrm{H}^{+}$by $\mathrm{DPPH}^{*}$ from the added bacterioruberin and highlighted the free radical scavenging property of bacterioruberin carried out using similar method of $\mathrm{DPPH}^{\circ}$, as reported by Biswas et al. (2016), Squillaci et al. (2017) and Hou and Chi (2018). The extent of change in color corresponded to the $\mathrm{H}^{+}$received from the donor bacterioruberin molecule. 

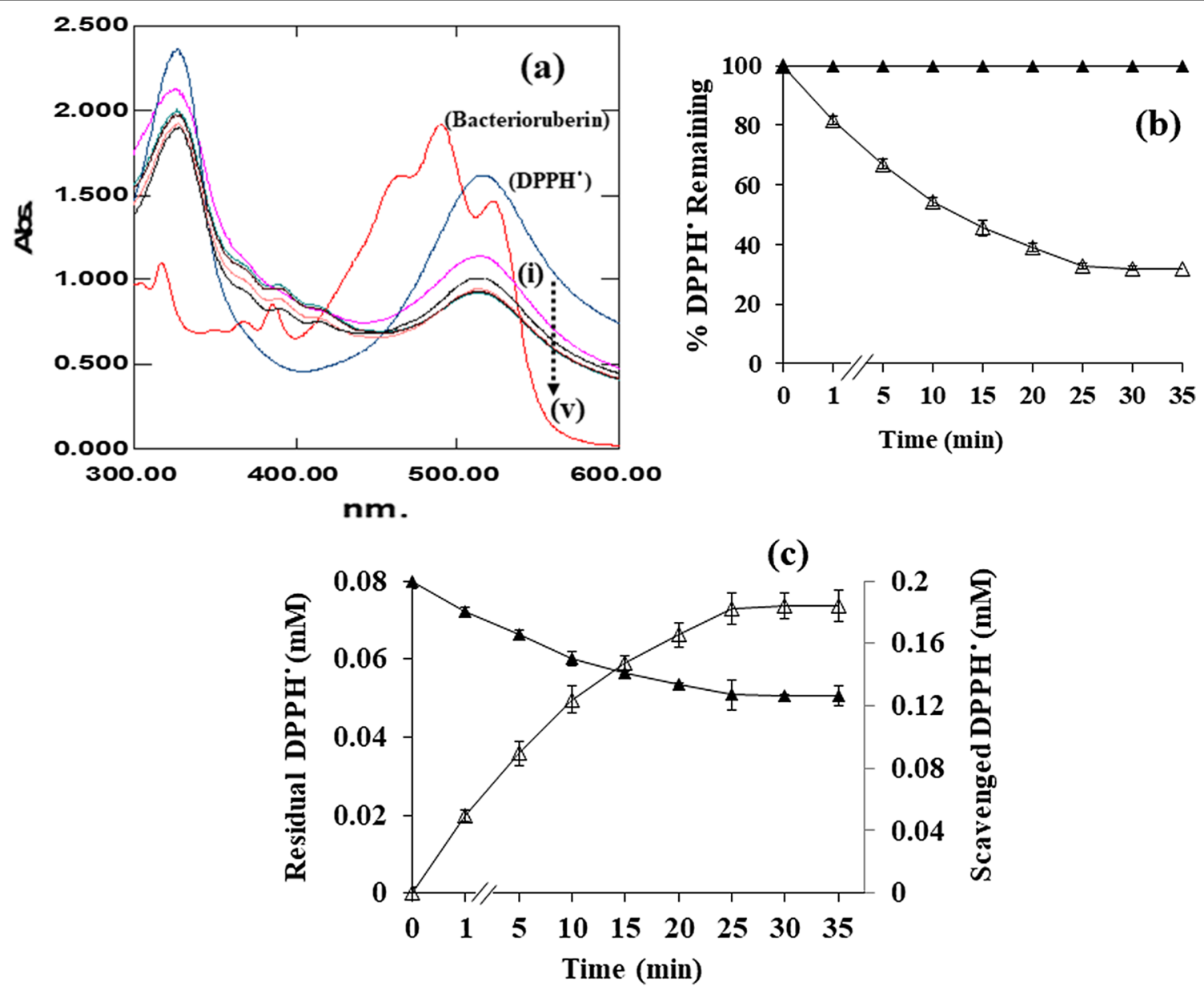

Fig. 3 a Visible absorption spectrum of $13 \mu \mathrm{M}$ bacterioruberin in methanol, $0.2 \mathrm{mM}$ methanolic DPPH' and (i-iv) bacterioruberin-DPPH' interaction; b $0.2 \mathrm{mM} \mathrm{DPPH}^{*}$ remains steady at $517 \mathrm{~nm}$ in the absence of bacterioruberin (filled triangle) and $0.2 \mathrm{mM} \mathrm{DPPH}^{*}$ in the presence of $13 \mu \mathrm{M}$ of bacterioruberin at $517 \mathrm{~nm}$ (open triangle); c residual concentration of $\mathrm{DPPH}(\mathrm{mM})$ monitored at $\mathrm{A}_{517}$ in the presence of bacterioruberin: residual $\mathrm{DPPH}^{*}$ (filled triangle) and scavenged DPPH' (open triangle). Data are expressed as mean \pm SD of three independent experiments

Free radical scavenging activity of bacterioruberin was monitored as a function of time. The addition of $13 \mu \mathrm{M}$ of bacterioruberin to $0.2 \mathrm{mM} \mathrm{DPPH}^{*}$ decreased its absorbance at $517 \mathrm{~nm}$, in the dark at $28^{\circ} \mathrm{C}$. In contrast, the absorbance of control $\mathrm{DPPH}^{\circ}$ at $517 \mathrm{~nm}$ remained unchanged for over $30 \mathrm{~min}$ (Fig. $3 \mathrm{~b}$ ) and indicated that it did not undergo auto-oxidation nor was affected by the environment in which the reaction was carried out. The purple color of $\mathrm{DPPH}^{*}$ changed to yellow with time, as $\mathrm{DPPH}^{\cdot}$ received an electron or a $\mathrm{H}^{+}$ from bacterioruberin, the donor molecule. The simultaneous decrease in \% $\mathrm{DPPH}^{*}$ remaining was noted; $81 \%$ on addition of bacterioruberin $(13 \mu \mathrm{M} / 0.013 \mathrm{mM})$ within $1 \mathrm{~min}, 66 \%$ at $5 \mathrm{~min}, 54 \%$ at $10 \mathrm{~min}, 45 \%$ at $15 \mathrm{~min}, 38 \%$ at $20 \mathrm{~min}, 32 \%$ at $25 \mathrm{~min}$ and remained steady at $31 \%$ from 30 min onwards (Fig. 3b).
Further, as seen in Fig. 3c, the $\mathrm{DPPH}^{*}$ was converted to DPPH-H molecule inversely proportional to the decay of radical till steady state. At $30 \mathrm{~min}$, an amount of $0.073 \mathrm{mM} \mathrm{DPPH}^{*}$ was converted to DPPH-H.

The subsequent slower rate pointed to the role of slow secondary reactions, possibly involving dimerization of phenol-derived radicals. The dependence of absorbance of $A_{B}(517 \mathrm{~nm})$ and $A_{S}(517 \mathrm{~nm})(\mathrm{t}=\mathrm{x})$ is therefore exponential and a power function, obtained by nonlinear regression analysis. The reaction occurs via the HAT radical mechanism wherein $\mathrm{H}^{+}$is donated by bacterioruberin as in $\mathrm{ArOH}+\mathrm{DPPH}^{*}=\mathrm{ArO}^{-}+\mathrm{DPPH}-\mathrm{H}$ and is possibly similar to the reactivity of the antioxidant present in Corchorus olitorius (C.olitorius) and Vernonia amygdalina (V. amygdalina) towards DPPH' (Yusuff et al. 2019). 
Table 1 Evaluation of $\mathrm{EC}_{50}$ from bacterioruberin-DPPH`interaction

\begin{tabular}{|c|c|c|c|c|c|c|c|}
\hline \multirow{3}{*}{$\begin{array}{l}\log (M) \\
\text { [Bacterioruberin] }\end{array}$} & \multicolumn{7}{|c|}{ \% DPPH' RSA } \\
\hline & \multicolumn{5}{|c|}{ Experiment No } & \multirow[t]{2}{*}{ Mean } & \multirow[t]{2}{*}{ SD } \\
\hline & 1 & 2 & 3 & 4 & 5 & & \\
\hline-6.091 & $6.5^{*}$ & $7.1^{*}$ & $6.98^{*}$ & $7.2^{*}$ & $6.68^{*}$ & 6.89 & 0.29 \\
\hline-5.966 & 9.8 & 9.2 & 9.21 & 9.5 & 9.7 & 9.48 & 0.27 \\
\hline-5.869 & 13.65 & 14.02 & 14.61 & 14.8 & 13.76 & 14.16 & 0.51 \\
\hline-5.568 & 25.47 & 23.44 & 24.32 & 24.8 & 23.2 & 24.24 & 0.94 \\
\hline-5.267 & 36.48 & 38.98 & 37.65 & 38.8 & 36.6 & 37.70 & 1.17 \\
\hline-5.091 & 42.7 & 43.21 & 44.52 & 42.8 & 44.6 & 43.56 & 0.92 \\
\hline-4.966 & 57.7 & 59.8 & 60 & 58.6 & 60.2 & 59.26 & 1.07 \\
\hline-4.869 & 66.78 & 68.9 & 70 & 68.4 & 72.2 & 69.25 & 2.01 \\
\hline-4.693 & 75.29 & 75 & 79 & 78.2 & 76.4 & 76.77 & 1.76 \\
\hline-4.568 & 80.77 & 81.77 & 81.23 & 82.4 & 80.6 & 81.35 & 0.74 \\
\hline-4.471 & 93.82 & $94.22^{*}$ & 93.21 & 93.2 & $94.6^{*}$ & 93.81 & 0.61 \\
\hline-4.392 & 93.87 & 92.11 & $93.22^{*}$ & 92.4 & 93.6 & 93.04 & 0.75 \\
\hline-4.267 & $93.87^{*}$ & 93.12 & 92.23 & $93.4^{*}$ & 92.8 & 93.08 & 0.61 \\
\hline $\log \mathrm{EC}_{50}$ & -5.15 & -5.18 & -5.19 & -5.20 & -5.20 & -5.18 & 0.01 \\
\hline $\mathrm{EC}_{50}[\mathrm{M}]$ & $6.93 \times 10^{-6}$ & $6.60 \times 10^{-6}$ & $6.45 \times 10^{-6}$ & $6.26 \times 10^{-6}$ & $6.28 \times 10^{-6}$ & $6.50 \times 10^{-6}$ & 0.27 \\
\hline $\mathrm{EC}_{50}[\mu \mathrm{M}]$ & 6.93 & 6.60 & 6.45 & 6.26 & 6.28 & 6.50 & 0.27 \\
\hline
\end{tabular}

*Minimum and maximum responses used for computing the $50 \%$ maximal response

The \% DPPH'RSA values are obtained from five independent experiments and results expressed as mean \pm SD

The Log $[\mathrm{M}] \mathrm{EC}_{50}$ values for bacterioruberin is computed from Fig. $4 \mathrm{a}, \mathrm{b}$

\section{Free radical scavenging kinetics at different concentrations of bacterioruberin}

Data at column 1 under experiment no in Table 1 was used to construct a concentration-effect curve (Fig. 4a) using the GraphPad Prism 9 statistical model with the built-in equation; Asymmetric (five-parameter, 5P), as also employed by Chen et al. (2013). From the minimum and maximum response, the amount required to scavenge $50 \%$ of the original concentration or $50 \%$ maximal response was calculated. The $50 \%$ maximal response was interpolated to the $\mathrm{X}$-axis. Also, A and B were selected on the $y$-axis as two closest points on either side of the $50 \%$ maximal response from the raw data. These points were then interpolated as $\mathrm{D}$ and $\mathrm{C}$ values on the $\mathrm{x}$-axis.

From Fig. 4a, b and Table 1, the following values were obtained:

$100 \%$ response calculated from the baseline (minimum) and maximum data was $87.37 \%$ and hence the $50 \%$ maximal response was fixed at $43.68 \%$; $A=58.33 \%$; $B=36.67 \% ; C=-5.25 \log [\mathrm{M}] ; D=-4.97 \log [\mathrm{M}]$.

Equation (3) was applied to experimental data from column 1 of Table 1 , and the following values were calculated:

Response interval $(y)$ between responses $A$ and $B=21.66 \%$; the interval between $50 \%$ maximal response and the next highest concentration $\left(y^{\prime}\right)=14.65 \%$; $x=5.25-4.97=0.28$

$$
\begin{aligned}
& \mathrm{EC}_{50}=D-\frac{(A-50 \% \text { max response }) \cdot x}{y} \\
& \mathrm{EC}_{50}=-4.97-\frac{(58.33-43.68) .0 .28}{21.66} \\
& \mathrm{EC}_{50}=-4.97-0.189 \log \text { moles } \\
& \mathrm{EC}_{50}=-5.15 \log \text { moles }
\end{aligned}
$$

The effectiveness of $\mathrm{EC}_{50}$ of bacterioruberin in scavenging $50 \%$ of $0.2 \mathrm{mM} \mathrm{DPPH}^{*}$ free radicals, calculated using the right-angled triangle method of Alexander et al. 1999, was therefore taken as $6.50 \mu \mathrm{M} \pm 0.27(4.81 \mu \mathrm{g} / \mathrm{mL} \pm 0.2)$ (Fig. 4a; Table 1) and that reported for beta-carotene was $18 \mu \mathrm{M} \pm 0.2(10 \mu \mathrm{g} / \mathrm{mL} \pm 0.2)$ which was three times lower than bacterioruberin. This is a very simple, precise and rapid method for the calculation of the $\mathrm{EC}_{50}$, (Ralevic et al. 1995) and does not require expensive computational aids, thus making the technique particularly useful for laboratory calculations (Alexander et al. 1999).

A number of reports on $\mathrm{EC}_{50}$ of bacterioruberin from haloarchaea are available in literature, but they do not match the concentration of $0.2 \mathrm{mM} \mathrm{DPPH}^{*}$ which is employed in this study even though the fixed time of 30 min was used. However, from reported $\mathrm{EC}_{50}$ values in $\mu \mathrm{g} / \mathrm{mL}$, we equated the $\mathrm{EC}_{50}$ required to scavenge $0.2 \mathrm{mM}$ $\mathrm{DPPH}^{*}$ so as to compare the results obtained in this study. Extract from the cells of Haloterrigena turkmenica 

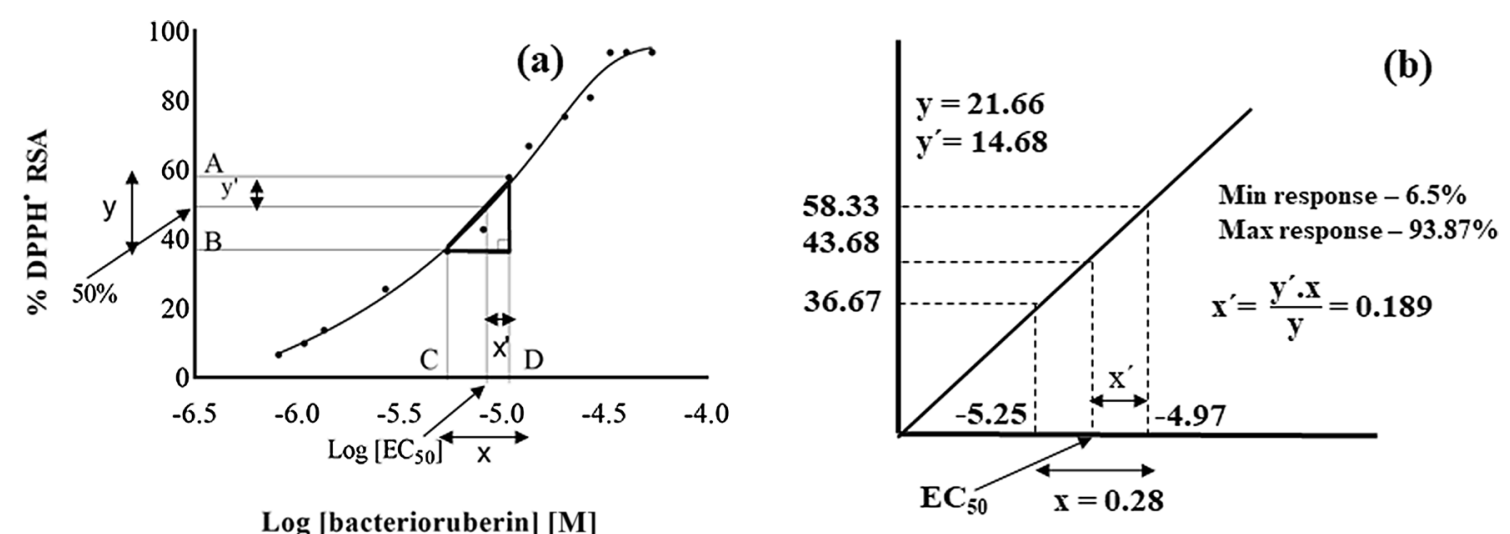

Log [bacterioruberin] [M]

(c)

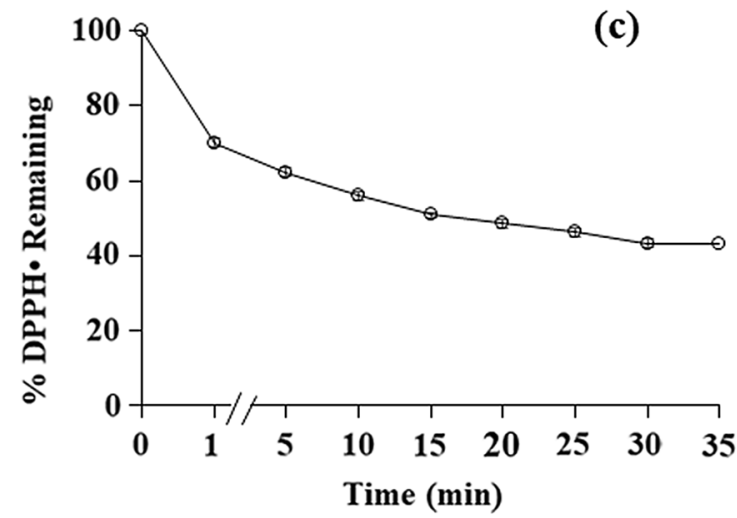

Fig. 4 a The concentration-response curve of bacterioruberin obtained GraphPad Prism 9 (San Diego, CA) statistical program with the built-in equation for nonlinear regression, i.e. Asymmetric (five-parameter, 5P) statistical model. The nearest recorded responses (A and B) of each experimental concentration ( $D$ and $C$ ), nearly equidistant on either side of the $\mathrm{EC}_{50}$ and forming a right-angled triangle as in method of Alexander et al. (1999); $\boldsymbol{b}$ graphic magnification of right-angled triangle of data from experiment No. 1 (Table 1) for calculation of the $\mathrm{EC}_{50}$ of bacterioruberin using the right-angled triangle method; $\mathbf{c}$ time to reach steady state $\mathrm{TEC}_{50}$ with the $\mathrm{EC}_{50}$ concentration of bacterioruberin. Data are expressed as mean \pm SD of five independent experiments

with $\mathrm{C}_{50}$ bacterioruberin (Squillaci et al. 2017) displayed an $\mathrm{IC}_{50}$ value of $8.98 \mu \mathrm{g} / \mathrm{mL}$. Hou and Chi (2018), found that $2.22 \mu \mathrm{g} / \mathrm{mL}$ of bacterioruberin from Haloferax volcanii and $160 \mu \mathrm{g} / \mathrm{mL}$ of bacterioruberin also obtained from Haloferax sp. BKW301 (Biswas et al. 2016) was required to scavenge $50 \%$ of $0.2 \mathrm{mM}^{\mathrm{DPPH}}{ }^{*}$. Comparing the $\mathrm{EC}_{50}$ value of bacterioruberin obtained in this study, the order of effectiveness of bacterioruberin was from Haloferax volcanii $>$ Haloferax alexandrinus GUSF-1 $>$ Haloterrigena turkmenica. In another study involving the antioxidant activity of bacterioruberin rich extracts, which was assessed using $\mathrm{DPPH}^{*}$ assay combined with electron paramagnetic resonance analysis, it was reported that $33.3 \mu \mathrm{g} / \mathrm{mL}$ scavenged $50 \%$ of $0.2 \mathrm{mM}^{\circ} \mathrm{DPPH}^{*}$ ) (Zalazar et al. 2019), eight times than $4.81 \mu \mathrm{g} / \mathrm{mL}$ of bacterioruberin from this study.

Figure $4 \mathrm{c}$ depicts the $\mathrm{DPPH}^{*}$ decolorization the $\mathrm{EC}_{50}$ $(6.50 \mu \mathrm{M} / 4.81 \mu \mathrm{g} / \mathrm{mL})$ of bacterioruberin, which progressed steadily at $517 \mathrm{~nm}$, till it reached a steady-state saturation i.e., maximum decrease in $\mathrm{DPPH}^{*}$ in 30 min; therefore, the $\mathrm{TEC}_{50}$ for bacterioruberin was fixed at $30 \mathrm{~min}$.

The antiradical efficiency is the reflection of a combination of kinetic and static approaches to characterize the antioxidant efficiency of a molecule (Huang et al. 2005). The antiradical efficiency of bacterioruberin deduced according to Sánchez-Moreno et al. $1998\left(\mathrm{EC}_{50}\right.$ calculated as: $\mathrm{g}$ Bacterioruberin $\left./ \mathrm{Kg} \mathrm{DPPH}{ }^{*}=61.04 \pm 2.58\right)$ was $54.7 \times 10^{-3} \pm 2.24$, which with $\mathrm{TEC}_{50}$ of $30 \mathrm{~min}$, fitted with an intermediate decay similar to that reported for gallic acid, tannic acid and $\alpha$-tocopherol and showed a very high efficiency as characterized by Sánchez-Moreno et al. 1998.

Bacterioruberin had an antiradical power (ARP) of $30.77 \pm 1.27$ calculated from the $\mathrm{EC}_{50}$ ( $\mu$ moles of bacterioruberin/ $\mu$ mole of $\left.\mathrm{DPPH}^{*}=0.03 \pm 0.017\right)$ using the equation according to Mishra et al. 2012, higher than that reported for all compounds tested in their study. Further 
the stoichiometry deduced was found to be $0.06 \pm 0.002$ and reduced $15.38 \pm 0.63$ molecules of $\mathrm{DPPH}^{\circ}$. It is pertinent to note that the stoichiometry and number of reduced $\mathrm{DPPH}^{*}$ for bacterioruberin have not been reported earlier.

Additionally, the antioxidant activity index (AAI) for bacterioruberin was calculated from $C_{\mathrm{f}} / \mathrm{EC}_{50}$, (taken as $\mu \mathrm{g} / \mathrm{mL}$ ) as $16.38 \pm 0.67$, which is $>2$, hence a strong antioxidant as per Scherer and Godoy (2009) antioxidant categories. Furthermore, comparing the AAI of bacterioruberin with AAI values of different standard antioxidants given by Scherer and Godoy 2009, the antioxidant activity index would be between protochatechuic acid $20.17>$ bacterioruberin (this study) $16.38>$ quercetin 15.92 .

Many attempts to explain the structure-activity relationship of some polyphenols are reported in the literature. It is known that the monophenols are less efficient than the polyphenols and that the number of hydroxyl groups is an important factor that enhances activity (Cuvelier et al. 1992; Shahidi et al. 1992; Salah et al. 1995). The accessibility of the radical center of $\mathrm{DPPH}^{*}$ to each polyphenol also contributes to the antioxidant power obtained (Yoshida et al. 1989). Another important parameter of antioxidant action is the stoichiometry of reactants which is the amount of antioxidant required theoretically to reduce $100 \%$ of $\mathrm{DPPH}^{\cdot}$ radicals. Bacterioruberin has an extensive system of 13 conjugated double bond, two acyclic phi $\phi$ end groups, four $\mathrm{OH}$ at positions $\mathrm{C}-1, \mathrm{C}-1^{\prime}, \mathrm{C}-3^{\prime \prime}, \mathrm{C}-3^{\prime \prime \prime}$. The length, conjugated double bonds and functional groups of a molecule are reported to contribute to the antioxidant capacity (Mandelli et al. 2012) and this explains the lower $E_{50}$ values and corresponding kinetic parameters.

The conversion of $\mathrm{DPPH}^{*}$ to $\mathrm{DPPH}-\mathrm{H}$ was carried out at fixed $0.2 \mathrm{mM}$ concentration of $\mathrm{DPPH}^{*}$ and different concentrations of bacterioruberin, and hence represented by the equation $\left.\ln \left[\mathrm{DPPH}^{\circ}\right]_{t}=\ln \left[\mathrm{DPPH}^{*}\right]_{0}\right]_{0} k_{\text {obs }} t$, where $\left[\mathrm{DPPH}^{*}{ }^{\circ}\right]_{t=0}$ is the concentration of radical at the $t=0$; $\left(\mathrm{DPPH}_{\mathrm{C}}\right)_{t=30}$ is the concentration of the radical at steady time $t=30, k_{\mathrm{obs}}$ is therefore the pseudo-firstorder rate constant obtained for the fixed reaction time of $30 \mathrm{~min}$. The second-order rate constant $k_{2}$ deduced from slope of the plot of $k_{\mathrm{obs}} \mathrm{v} / \mathrm{s}$ concentration of $\mathrm{DPPH}^{\cdot}$ (Fig. 5) was $2.76 \times 10^{-5} \pm 0.001 \mu \mathrm{M}^{-1} \mathrm{~s}^{-1}$ for the bacterioruberin- $\mathrm{DPPH}^{*}$ interaction at a steady state of $30 \mathrm{~min}$. In the absence of studies reporting rate constant for bacterioruberin, the rate constant value of $2.76 \times 10^{-5} \pm 0.001 \mu \mathrm{M}^{-1} \mathrm{~s}^{-1}$ obtained in this study was found to be greater than that of curcumin $\left(2 \times 10^{-5} \pm\right.$ $0.12 \mu \mathrm{M}^{-1} \mathrm{~s}^{-1}$ ) but lower than the value reported for gallic acid $4 \times 10^{-5} \pm 0.4 \mu \mathrm{M}^{-1} \mathrm{~s}^{-1}$ by Mishra et al. 2012,

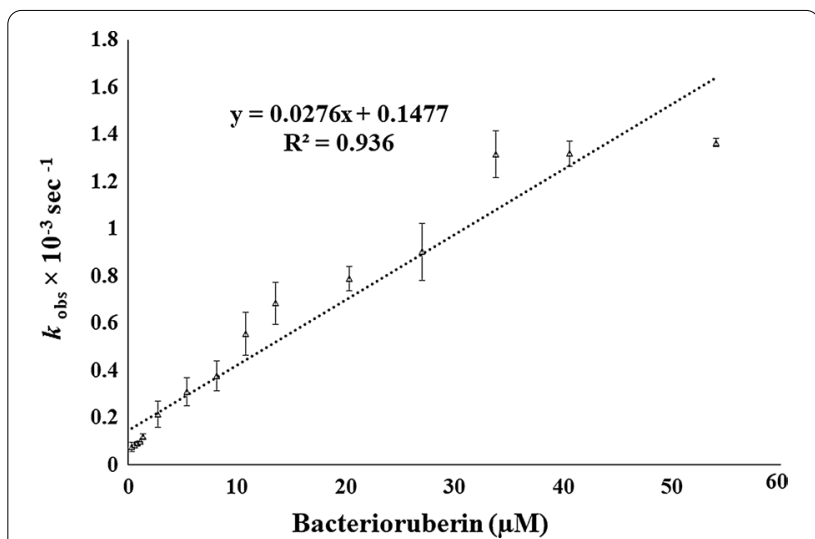

Fig. 5 Plot of pseudo-first-order rate constant $\left(k_{\text {obs }}\right)$ versus bacterioruberin concentration. All measurements were carried out in methanol medium. Data are expressed as mean \pm SD of five independent experiments. The second-order constant $k_{2}$ was calculated from the slope of this plot

although both of these molecules being unrelated to bacterioruberin in molecular weight.

Expression of results in terms of the kinetic approach does not take into account only the activity of an antioxidant but also provides information on how quickly the antioxidant acts (Squillaci et al. 2017). Hence, it is pertinent to note that results of antioxidant activity based on kinetic data and on the measurement at a fixed endpoint should be combined so as to provide comprehensive information of the total antioxidant activity of a compound. This is the first study reporting the kinetics of free radical scavenging by bacterioruberin from a genetically unmodified Haloferax alexandrinus GUSF-1 investigated by the simple, conventional colorimetric assay for $\mathrm{DPPH}^{\circ}$ chromogen and monitored using an easily available spectrophotometer and highlighting its unique antioxidant potential.

\section{Conclusions}

In summary, this study on the kinetic behavior of antioxidant, bacterioruberin, from cells of Haloferax alexandrinus GUSF-1(KF796625) on decay of $0.2 \mathrm{mM}$ $\mathrm{DPPH}^{*}$ enabled us to fix $\mathrm{EC}_{50}$ at $6.50 \mu \mathrm{M} \pm 0.27(4.81 \mu \mathrm{g} /$ $\mathrm{mL} \pm 0.2$ ) and $\mathrm{TEC}_{50}$ of $30 \mathrm{~min}$ and also the other kinetic parameters such as AAI at $16.38 \pm 0.67$, ARP at $30.77 \pm 1.27$ and the ARE of bacterioruberin was $54.7 \times 10^{-3} \pm 2.24$, showed a stoichiometric value of $0.06 \pm 0.002$ and reduced $15.38 \pm 0.63$ molecules of $\mathrm{DPPH}^{\circ}$. These kinetic parameters are not yet reported for bacterioruberin interacting with $\mathrm{DPPH}^{*}$. Further, the scavenging reaction of $\mathrm{DPPH}^{*}$ by bacterioruberin was pseudo-first order with a second- order rate constant 
$k_{2} 2.76 \times 10^{-5} \pm 0.001 \mu \mathrm{M}^{-1} \mathrm{~s}^{-1}$ fixed at a fixed time of $30 \mathrm{~min}$.

Additionally, the production of $\mathrm{C}_{50}$ carotenoid bacterioruberin by cells of Haloferax alexandrinus GUSF1 (KF796625) is economical, easy to extract, purify and is expected to be helpful for use in the food production industry, antioxidant supplements and cosmetics. Besides, the application of the simple conventional method of $\mathrm{DPPH}^{*}$ free radical scavenging, monitored using easily available instruments and methodology will certainly help in the effective use of any antioxidant compound.

\begin{abstract}
Abbreviations
DPPH: 1,1-Diphenyl-2-picrylhydrazyl; TLC: Thin-layer chromatography; NTYE: Tryptone Yeast Extract containing 25\% (w/v) NaCl; \% DPPH'RSA: \% 1,1-Diphenyl-2-picrylhydrazyl radical scavenging activity; LC-MS: Liquid Chromatography-Mass Spectroscopy; EC $_{50}$ : Effective concentration; TEC 50 : Time required to attain the steady state with $\mathrm{EC}_{50}$ concentration of bacterioruberin; ARP: Antiradical power; ARE: Antiradical efficiency; AAl: Antioxidant activity index.
\end{abstract}

\section{Supplementary Information}

The online version contains supplementary material available at https://doi. org/10.1186/s40543-021-00293-3.

Additional file 1: Fig. 1. Standard curve of DPPH*

\section{Acknowledgements}

The authors thank VerGo Pharma Research Laboratories Pvt. Ltd., Verna- Goa, India, for the LC-MS facility.

\section{Authors' contributions}

JJA planned and carried out the experiments. IJF and JJA inferred and analyzed the observations. IJF designed the manuscript. Both authors read and approved the final manuscript.

\section{Funding}

Not applicable.

\section{Availability of data and materials}

Haloferax alexandrinus GUSF-1 (GenBank accession number KF796625). Gen bank: http://www.ncbi.nlm.nih.gov.

\section{Declarations}

Competing interests

The authors declare that they have no competing interests.

Received: 10 April 2021 Accepted: 1 September 2021

Published online: 30 September 2021

\section{References}

Abbes M, Baati H, Guermazi S, Messina C, Santulli A, Gharsallah N, Ammar E. Biological properties of carotenoids extracted from Halobacterium halobium isolated from a Tunisian solar saltern. BMC Complement Altern Med. 2013:13:255. https://doi.org/10.1186/1472-6882-13-255.

Alexander B, Browse DJ, Reading SJ, Benjamin IS. A simple and accurate mathematical method for calculation of the $E_{50}$. J Pharmacol Toxicol Methods. 1999;41(2-3):55-8. https://doi.org/10.1016/s1056-8719(98) 00038-0.
Alvares JJ, Furtado IJ. Extremely halophilic Archaea and Eubacteria are responsible for free radical scavenging activity of solar salts of Goa-India. Glob J Bio-Sci Biotechnol. 2018:7(2):242-54.

Alvares JJ, Furtado IJ. Characterization of multicomponent antioxidants from Haloferax alexandrinus GUSF-1 (KF796625). 3 Biotech. 2021;11:58. https:// doi.org/10.1007/s13205-020-02584-9.

Arnao MB. Some methodological problems in the determination of antioxidant activity using chromogen radicals: a practical case. Trends Food Sci Technol. 2000;11(11):419-21. https://doi.org/10.1016/s0924-2244(01) 00027-9.

Asker D, Awad T, Ohta Y. Lipids of Haloferax alexandrinus Strain TM': an extremely halophilic canthaxanthin producing archaeon. J Biosci Bioeng. 2002;93(1):37-43. https://doi.org/10.1016/S1389-1723(02)80051-2.

Biswas J, Haque FN, Paul AK. Carotenogenesis in Haloferax sp. strain BKW301, a halophilic archaeon from Indian solar salterns. J Adv Microbiol. 2016;1(3):1-11. https://doi.org/10.9734/JAMB/2016/31559.

Brand-Williams W, Cuvelier ME, Berset C. Use of a free radical method to evaluate antioxidant activity. Lebensm Wiss Technol. 1995;28:25-30.

Chen Z, Bertin R, Froldi G. EC estimation of antioxidant activity in $\mathrm{DPPH}^{*}$ assay using several statistical programs. Food Chem. 2013:138(1):414-20. https://doi.org/10.1016/j.foodchem.2012.11.001.

Cuvelier M-E, Richard H, Berset C. Comparison of the antioxidative activity of some acid-phenols: structure activity relationship. Biosci Biotechnol Biochem. 1992;56(2):324-5. https://doi.org/10.1271/bbb.56.324.

Deng J, Cheng W, Yang G. A novel antioxidant activity index (AAU) for natural products using the DPPH assay. Food Chem. 2011;125(4):1430-5. https:// doi.org/10.1016/j.foodchem.2010.10.031.

Firuzi O, Miri R, Tavakkoli M, Saso L. Antioxidant therapy: current status and future prospects. Curr Med Chem. 2011;18(25):3871-88. https://doi.org/ 10.2174/092986711803414368.

Guerin M, Huntley ME, Olaizola M. Haematococcus astaxanthin: applications for human health and nutrition. Trends Biotechnol. 2003;21(5):210-6. https://doi.org/10.1016/s0167-7799(03)00078-7.

Hou J, Cui H-L. In vitro antioxidant, antihemolytic, and anticancer activity of the carotenoids from halophilic archaea. Curr Microbiol. 2018;75(3):26671. https://doi.org/10.1007/s00284-017-1374-z

Huang D, Ou B, Prior RL. The chemistry behind antioxidant capacity assays. J Agric Food Chem. 2005;53:1841-56. https://doi.org/10.1021/jf030723c.

Mandelli F, Miranda VS, Rodrigues E, Mercadante AZ. Identification of carotenoids with high antioxidant capacity produced by extremophile microorganisms. World J Microbiol Biotechnol. 2012;28(4):1781-90. https://doi. org/10.1007/s11274-011-0993-y.

Markovic Z. Study of the mechanisms of antioxidative action of different antioxidants. J Serbian Soc Comput Mech. 2016;10(1):135-50.

Mishra K, Ojha H, Chaudhury NK. Estimation of antiradical properties of antioxidants using DPPH' assay: a critical review and results. Food Chem. 2012;130:1036-43. https://doi.org/10.1016/j.foodchem.2011.07.127.

Raghavan TM, Furtado I. Occurrence of extremely halophilic Archaea in sediments from the continental shelf of west coast of India. Curr Sci. 2004;86(8):1065-7.

Ralevic V, Hoyle CHV, Burnstock G. Pivotal role of phosphate chain length in vasoconstrictor versus vasodilator actions of adenine dinucleotides in rat mesenteric arteries. J Physiol. 1995:483(3):703-13.

Ronnekleiv M, Liaaen-Jensen S. Bacterial carotenoids. 53*, C50-carotenoids 23; Carotenoids of Haloferax volcanii versus other halophilic bacteria. Biochem Syst Ecol. 1g995;23(6):627-734. https://doi.org/10.1016/03051978(95)00047-X

Salah N, Miller NJ, Paganga G, Tijburg L, Bolwell GP, Rice-Evans C. Polyphenolic flavanols as scavengers of aqueous phase radicals and as chain-breaking antioxidants. Arch Biochem Biophys. 1995;332(2):339-46. https://doi.org/ 10.1006/abbi.1995.1473.

Sánchez-Moreno C, Larrauri JA, Saura-Calixto F. A procedure to measure the antiradical efficiency of polyphenols. J Sci Food Agric. 1998;76(2):270-6. https://doi.org/10.1002/(SICI)1097-0010(199802)76:2\%3c270::AID-JSFA9 45\%3e3.0.CO;2-9.

Scherer R, Godoy HT. Antioxidant activity index (AAI) by the 2, 2-diphenyl1-picrylhydrazyl method. Food Chem. 2009;112:654-8. https://doi.org/10. 1016/j.foodchem.2008.06.026.

Sequeira F. Microbiological study of salt pans of Goa. Master of Science dissertation. Goa University, India; 1992. 
Shahidi F, Janitha PK, Wanasundara PD. Phenolic antioxidants. Crit Rev Food Sci Nutr. 1992;32(1):67-103. https://doi.org/10.1080/10408399209527581.

Shahmohammadi HR, Asgarani E, Terato H, Saito T, Ohyama Y, Gekko K, Yamamoto $\mathrm{O}$, Ide $\mathrm{H}$. Protective roles of bacterioruberin and intracellular $\mathrm{KCl}$ in the resistance of Halobacterium salinarium against DNA-damaging agents. J Radiat Res. 1998;39:251-62.

Squillaci G, Parrella R, Carbone V, Minasi P, La-Cara F, Morana A. Carotenoids from the extreme halophilic archaeon Haloterrigena turkmenica: identification and antioxidant activity. Extremophiles. 2017;21:933-45. https:// doi.org/10.1007/s00792-017-0954-y.

Yatsunami R, Ando A, Yang Y, Takaichi S, Kohno M, Matsumura Y, Ikeda H, Fukui

T, Nakasone K, Fujita N, Sekine M, Takashina T, Nakamura S. Identifica-

tion of carotenoids from the extremely halophilic archaeon Haloarcula japonica. Front Microbiol. 2014;5:100. https://doi.org/10.3389/fmicb.2014. 00100.

Yoshida T, Mori K, Hatano T, Okumura T, Uehara I, Komagoe K, Fujita Y, Okuda T. Studies on inhibition mechanism of autoxidation by tannins and flavonoids. V. Radical-scavenging effects of tannins and related polyphenols on 1,1-diphenyl-2-picrylhydrazyl radical. Chem Pharm Bull. 1989;37(7):1919-21.

Yusuff OK, Abdul Raheem MAO, Mukadam AA, Sulaimon RO. Kinetics and mechanism of the antioxidant activities of C. olitorius and $V$. amygdalina by spectrophotometric and DFT methods. ACS Omega. 2019;4:13671-80.

Zalazar L, Pagola P, Miró MV, Churio MS, Cerletti M, Martínez C, Iniesta-Cuerda M, Soler AJ, Cesari A, De Castro R. Bacterioruberin extracts from a genetically modified hyperpigmented Haloferax volcanii strain: antioxidant activity and bioactive properties on sperm cells. J Appl Microbiol. 2019;126(3):796-810. https://doi.org/10.1111/jam.14160.

\section{Publisher's Note}

Springer Nature remains neutral with regard to jurisdictional claims in published maps and institutional affiliations.

\section{Submit your manuscript to a SpringerOpen ${ }^{\odot}$ journal and benefit from:}

- Convenient online submission

- Rigorous peer review

- Open access: articles freely available online

- High visibility within the field

- Retaining the copyright to your article

Submit your next manuscript at $\boldsymbol{\nabla}$ springeropen.com 